 \\ Open Access
}

\section{Understanding Domestic Tourists to Support COVID-19 Recovery Strategies - The Case of Aotearoa New Zealand}

\author{
Michael Lück ${ }^{\mathrm{a} *}$; Sabrina Seeler ${ }^{\mathrm{b}}$ \\ aAuckland University of Technology (AUT), School of Hospitality and Tourism, Auckland 0994, New Zealand; \\ ${ }^{b}$ West Coast University of Applied Sciences, DITF - German Institute for Tourism Research, Fritz-Thiedemann- \\ Ring 20, 25746 Heide, German.
}

*Correspondence: mlueck@aut.ac.nz

Received 31 January 2021; Revised 15 June 2021; Accepted 4 July 2021

\begin{abstract}
With international tourism at a standstill and domestic tourism being decisive in post-COVID-19 recovery strategies, tourism destinations need to turn their lenses more inwardly again. Pre-COVID-19 destination marketing and management strategies were often following neoliberal growth frameworks, focusing on the international visitor. Respectively, there is an abundance of consumer insights related to international demand, yet knowledge about the desires of domestic visitors is often lacking. It remains unclear how the previous outward-oriented lens has impacted the travel behaviour of domestic tourists. Based on 20 semi-structured interviews with multiple stakeholders across Aotearoa New Zealand, this research provides valuable insights into the country's domestic tourists. Findings reveal three core themes about domestic tourism pre-COVID-19: (1) Dispersal strategies resulted in spatial and temporal displacement; (2) Unrealistic domestic tourists holding on to the past; (3) Widespread blaming of 'others' and hiding of own misbehaviour. Given that it remains uncertain when international travel will resume, and the calls for a re-thinking of tourism that avoids going back to the old 'normal' and instead integrates more resilience and sustainability thinking, the stimulation of domestic demand should not only be temporary but a long-term strategy. It will be the task of policy makers and the tourism industry to make sure that New Zealanders re-discover their homeland while becoming better kaitiaki (guardians). This paper provides important theoretical insights and practical implications for post-COVID-19 recovery strategies of destinations.
\end{abstract}

KEYWORDS: domestic tourism; domestic marketing; tourism policy; COVID-19; postdisaster recovery; New Zealand

\section{Introduction}

The sudden and tremendous outbreak of COVID-19 in early 2020 lead to a standstill of global tourism. With the closure of international borders, lockdowns and curfews as well as cessation of air travel, destinations have shifted from having too many tourists and tendencies of overtourism to non-tourism (Gössling, Scott, \& Hall, 2020). The tourism industry is proposed to be one of the most heavily impacted industries worldwide, with tourism numbers 
expected to plummet by up to $80 \%$ (TravelMole, 2020), and potential losses of $20-30 \%$ of international tourism receipts (World Tourism Organization, 2020a).

A variety of travel restrictions leave deep economic scars in the tourism industry as repeated lockdowns are causing a major recession. While the first shock is overcome and tactical actions to respond to the crisis have been made, such as virtual tours or campaigns that spread hope to "dream now, visit later" (Skirka, 2020), calls for a re-thinking and transformation of the tourism industry beyond previously dominant neoliberal growth strategies and towards more sustainability and resilience become louder (Higgins-Desbiolles, 2020a; Niewiadomski, 2020). Higgins-Desbiolles (2020b) describes the arrival of COVID-19 as a "watershed moment" (p. 2) and highlights that the "COVID-19 pandemic crisis offers a rare and invaluable opportunity to rethink and reset tourism" (p. 11). This is echoed by the World Tourism Organization, which promotes sustainable tourism as the new normal (World Tourism Organization, 2020b), and scholars who critically note that there should not be a return to pre COVID-19 conditions. Rather, the crisis should be understood as a "temporary process of de-globalisation" (Niewiadomski, 2020, p. 1) and seen as an opportunity "to deeply reflect on our dominant worldview and our value system" (Ateljevic, 2020, p. 2). Similarly, through a critical and hopeful lens, Pernecky (2020) contends that "our momentary loss of tourism may bring with it a renewed appreciation and care, which has been eroded by rampant commodification and comatose consumerism" (p. 8). Alongside hope, scholars also emphasise that the future post COVID-19 will rely on the choices made (Ateljevic, 2020; Niewiadomski, 2020) and the recovery strategies pursued to become more resilient (Gössling et al., 2020). Ideas of resilience building have more recently attracted increasing attention in tourism research and are better understood as the capacity organisations, individuals and communities respond and adapt to change (Hall, Prayag, \& Amore, 2018). This may happen at a macro, meso or micro level (Prayag, 2020). While some scholars challenge the transformative potentials of this crisis as governments and businesses will most likely return to neoliberal growth models to regain economic viability (Hall, Scott, \& Gössling, 2020), there is little doubt that domestic tourism will temporarily gain centre stage, because it is the only life line many operators will have for a while (Gössling et al., 2020; Seeler \& Lück, 2020). An added benefit of the restricted long-haul flights and a focus on regional and domestic tourism is that it is good for the planet due to drastically reduced carbon emissions from air travel (Higham, 2020).

The importance of domestic tourism is further highlighted by the uncertainty about when cross-border travel will resume without restrictions and the underlying fear that the virus can be (re-)imported when international borders are open again. Adding fuel to this uncertainty are the frequent changes in restrictions, as is evident in the USA, Europe, New Zealand, and elsewhere. Rafat Ali, founder and CEO of Skift, for instance, proposes "radical localism" and discusses potential winners and losers in a domestic tourism scenario (Ali, 2020). Hesitation remains as there are doubts that revenue streams from domestic tourism will suffice (Kravchenko, 2020) and questions arise what this will mean for tourism operators and experience providers that heavily depend on international visitors. Given the pressing need for a more sustainable development of the tourism industry beyond economic prosperity and acknowledging the United Nation's (UN) 17 Sustainable Development Goals (United Nations, 2017), it also puts into question which role domestic tourism should play beyond short-term recovery after COVID-19, but also towards long-term sustainability and resilience. 
In the past, neoliberal growth frameworks have favoured international tourism (Niewiadomski, 2020) and national destination management organisations (DMOs), such as Tourism New Zealand, almost exclusively targeted their promotion towards attracting international guests (Tourism New Zealand [TNZ], 2020b). While infrastructure planning and policies were mostly driven by international demand and insights gained through, for instance, international visitor surveys, the needs and desires from the domestic market were often only peripherally considered. Various countries have implemented different COVID-19 management approaches, and domestic travel behaviour during the pandemic varied accordingly. For example, in Turkey individual regions had different quarantine requirements, which has influenced domestic inter-regional travel (Altunas \& Gok, 2021). Already prior to the outbreak of COVID-19 had the Nordic countries experienced steady or growing domestic travel based on a long tradition of outdoor recreation ("Friluftsliv"), which even increased during the crisis. In Germany, domestic demand almost exploded when travel restrictions were lifted leading to closure of roads to famous beaches over summer and ski fields in winter (Geißler, 2020; RND, 2020). Japan has even subsidised domestic travel through the provision of travel vouchers, which also led to crowding in popular places and capacity restrictions of some areas (Lück \& Aquino, in press). With the dire need to "win back their hearts" (Seeler \& Lück, 2020) and ensure that domestic guests will re-explore their home countries beyond the COVID-19 recovery stage, DMOs und tourism businesses will need to gain a better understanding of the domestic market and how the previously applied outwardoriented lens has impacted the travel behaviour of domestic tourists. This paper addresses these knowledge gaps to aid policy strategies, using Aotearoa New Zealand as an example.

\section{The Role of Domestic Tourism in Aotearoa New Zealand}

Tourism is the largest foreign exchange earner for Aotearoa New Zealand and has experienced continuous growth over the past years (TNZ, 2019). Domestic guests accounted for $57 \%$ of the 40.4 million commercial guest nights generated in the year ending June 2019 . Only few destinations have a larger share of international tourists compared to domestic guests year-round, and some experience an almost equal distribution in summer (Stats NZ, 2019a). Given that $58 \%$ of the total tourism expenditure is generated by domestic tourists (Stats NZ, 2019b), "fostering domestic tourism" was identified as one of the Top 10 actions in the national tourism strategy, even prior to the COVID-19 outbreak (Tourism Industry Aoteara [TIA], 2019b). However, Tourism New Zealand's (TNZ) legacy as the national entity to promote the country lies in attracting international tourists (TNZ, 2021). Only recently has TNZ started to provide educational information to the domestic market through extensive marketing campaigns (TNZ, 2019). As a direct response to COVID-19, the government has announced a 10 million New Zealand dollar recovery fund (TNZ, 2020b), has called for a reimagination of tourism amidst global travel restrictions, and has put TNZ in charge of establishing a business unit to stimulate domestic demand (TNZ, 2020a). With the realisation that consumer insights about the domestic market were largely neglected in the past, there is a call for more market knowledge that aids defining recovery strategies based on national demand. Based on a qualitative study, this paper illuminates areas that will need attention in the future of domestic tourism. 


\section{Research Methods}

A multiple stakeholder perspective was pursued with the aim to give a voice to representatives from tourism businesses, central, regional and local governments, regional tourism organisations (RTOs) and community members across Aotearoa New Zealand. A purposive sampling strategy was adopted followed by a snowball sampling technique to identify participants with the overall best fit for this research (Denscombe, 2017). Potential participants were invited using direct email invitations and were informed about their rights and responsibilities, such as confidentiality of all information provided. This two-step sampling approach allowed to reach data saturation after 20 semi-structed face-to-face interviews, meaning that additional interviews would not yield additional, valuable information and eventually codes leading to informational redundancy (Denscombe, 2017). All interviews were conducted in February 2020 across ten destinations on Aotearoa New Zealand's North and South Islands. Prior to the interviews, participants were asked whether there are any unresolved questions, were asked to sign a consent form and were informed that they would receive updates on any publications resulting from the research. An interview guide with pre-defined open-ended questions was used. Given the partly unsustainable tourism development in pre-COVID-19 Aotearoa New Zealand and the growing dissatisfaction among different stakeholder groups, interview participants were asked to share their sentiments of the then current development of tourism within their region and Aotearoa New Zealand as a whole. Thereby they were also asked to elaborate on the role of domestic tourism within destination management and marketing. After interview completion, the audio files were transcribed by the researchers themselves and were verified against the voice recordings to ensure accuracy, consistency and integrity. Afterwards, transcripts were sent to the research participants for validation. This process ensured transcript accuracy and encouraged a positive and trustworthy partnership. Once all interview transcripts were confirmed, an iterative process of manual and digital coding using NVivo 12 was implemented. The four-phased recursive coding process that was followed in this research was inspired by Braun and Clarke's (2006) six step coding approach and principles of thematic analysis (Figure 1). To eliminate possible bias, all steps were independently applied by both researchers. However, as coding in thematic analysis is always processed through the "researcher's analytical lens" (Saldaña, 2016, p. 7), it remains a subjective procedure yielding unavoidable deviations between any two researchers. In case of any deviations, transcripts were re-read, re-evaluated and codes refined until consistency and transparency were achieved. 


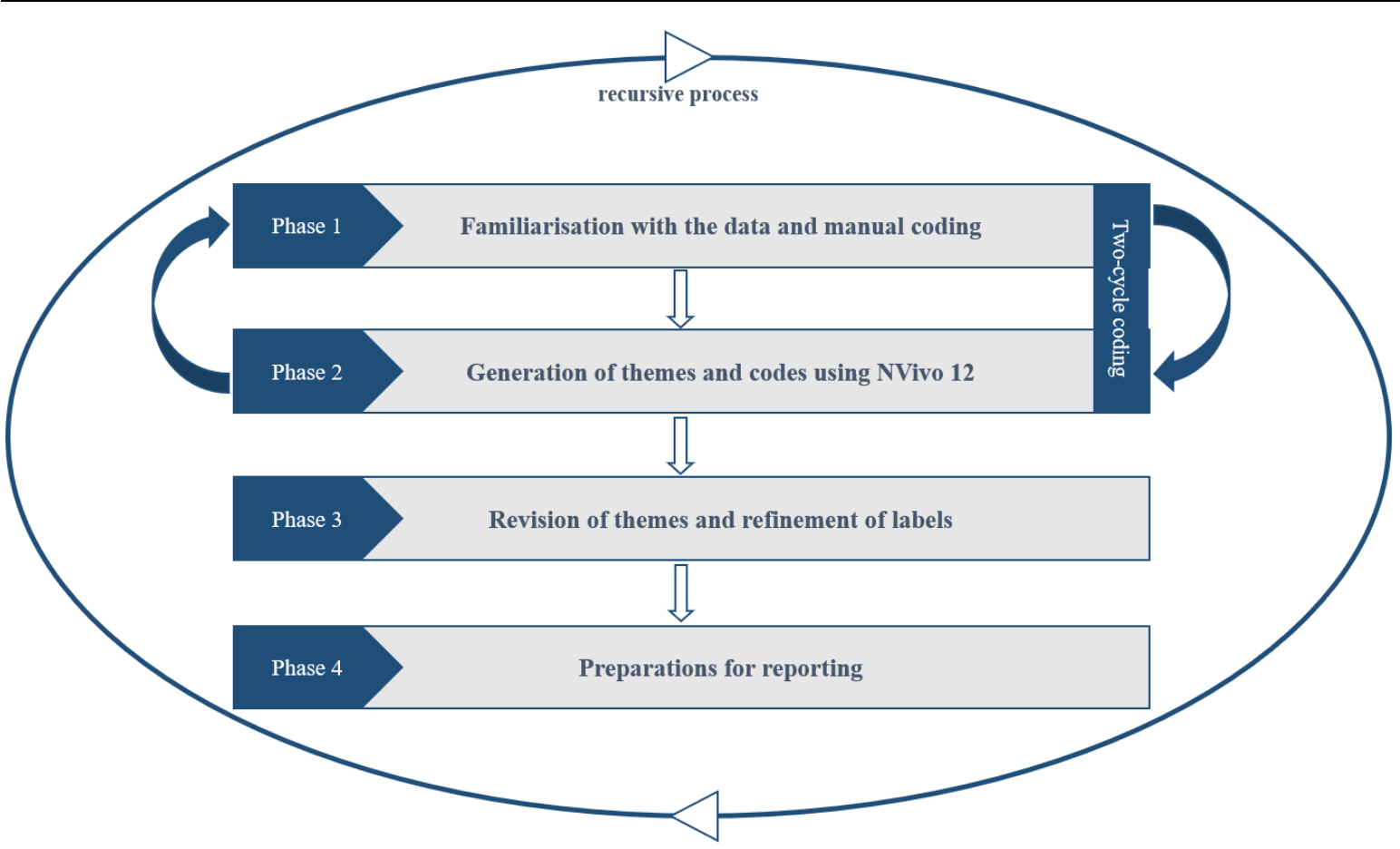

Figure 1: Four-phased recursive coding

The coded data were analysed following Braun and Clarke's (2006) principles of thematic analysis. As part of the university's ethics requirements, placeholders and pseudonyms (without revealing their specific location) are used to ensure confidentiality and participants are categorised into three stakeholder groups: Group 1: Community member / resident $(n=6)$; Group 2: regional or local council / central government agency $(n=8)$; Group 3: tourism business / RTOs $(n=6)$.

\section{Findings and Discussion}

\section{Displacement of domestic tourists as 'gap fillers'}

Official statistics demonstrate that the tourism industry's endeavours to achieve a better spatial spread and reduce seasonal fluctuations through attracting domestic visitors in the shoulder seasons and less visited destinations have been successful (TNZ, 2019). However, findings reveal that these temporal and spatial dispersal strategies correspond more to displacement:

Group2_R4: So, you definitely are seeing that people are trying to be more strategic or more tactical about how they plan their trips and how they do things and are trying to beat the crowds. They are trying to be logistic about it and we also see people choosing not to do things and also pushing out the seasons. [...] a lot of New Zealanders on the Great Walks [New Zealand's ten most popular multi-day hiking trails] now, they go in the shoulder seasons, they will trade-off the ability with the better weather for the chance that it is probably less busy.

Alongside forms of seasonal displacement to avoid crowds despite likely less ideal conditions, several forms of spatial displacement are noticed. For instance, places associated 
with high visitation, such as Queenstown or Akaroa are being actively avoided by locals as reflected on by one participant:

Group2_R6: My wife's family is from Christchurch and we are going there every year for Christmas [...] and we go to the Banks Peninsula, but we wouldn't go to Akaroa. We go to Little River, it is nice and quiet.

On the other hand, it means that locals and domestic visitors are pushed further and further into the backcountry:

Group2_R6: I think one of the things [...] I found interesting was that second and third and fourth level displacement. It is not just, 'this popular track is now very popular, you cannot go there. I used to go to this slightly less popular track, but now the very popular track is so busy that all the people that were normally going there are now forced to go to the slightly less popular one' [...] It wasn't only 'I cannot go here anymore, but I cannot go here and here and here and that forces me to go here'.

Throughout, participants stepped out of their professional role and reflected on their own experience as domestic tourists. They shared that they would love to have a holiday in their home country, but they refrained from it because it is "swamped with tourists" (Group1_R6). In the same vein, participants also critically remarked that neoliberal growth models aiming for quick profits, such as through cruise arrivals, are less sustainable. Findings reveal that destinations are missing the traditional domestic markets and are "missing the big picture, which is that we are losing the type of tourism that we were used to have" (Group1_R4). One participant also shared the difficulties when working with the domestic market as their travel patterns are less predictable: "Kiwis travelling on a whim based on the Tuesday weather forecast" (Group2_R7), highlighting the uncertainties of short-notice bookings.

\section{Domestic tourists 'hiding' behind reality}

Prior to COVID-19, some places across Aotearoa New Zealand had experienced tendencies of (temporal) overtourism, which have sparked discussions around threats to ecological integrity, physical capacity, infrastructure constrains, and community well-being (Higham, 2020; Insch, 2019). This has not only received media attention with headlines such as " $100 \%$ Pure Crowds: Is over-tourism ruining New Zealand's gems?" (referring to Tourism New Zealand's highly successful $20+$ year " $100 \%$ Pure New Zealand" marketing campaign), but has also contributed to a shifting mood in the population (Sabin, 2019; TIA, 2019a). While headlines such as the ones related to an "unruly" British family misbehaving while travelling in New Zealand (Hurley, 2019) have spurred assumptions that threats to Aotearoa New Zealand's fragile ecosystem and communities are attributable to international guests, our findings reveal that the blaming of international tourists is not entirely reflecting reality. Most destinations across Aotearoa New Zealand have a larger share of domestic tourists, meaning that impacts through overcrowding and peak visitation cannot be limited to international guests.

Group3_R1: Three quarters of [Destination X] visitors come from New Zealand; they are domestic visitors. So, the challenges we face, and as you say it would be easy to judge and blame the international visitors because they don't understand our culture and 
our environment. [Destination X's] challenge cannot only come from international visitors.

Another participant noted issues related to blaming international tourists for litter at a famous freedom camping spot and shared the following insight:

Group2_R6: Some locals got together and set up a camera and they watched it back and they noticed that pretty much every person that left some rubbish wasn't the freedom campers, it was local teenagers. That was kind of interesting that these locals got together to gather evidence to stop freedom camping only to find out that it is their nephews and nieces and neighbours that were causing the problems.

While this is not directly related to domestic tourists, it demonstrates how prejudice towards international freedom campers has evolved. So much so, that residents organised a petition to ban freedom camping, but only for international visitors (Foon, 2020). Similarly, participants shared that issues associated with freedom camping also arise due to a negligence of New Zealanders that the country, its population size, and general conditions have changed:

Group3_R4. My theory is, that most New Zealanders have had the pleasure, thanks to some friendly farmers in the past, to being able to camp wherever they like and they do believe that is a God-given right. Even though no longer they have a little car and a little tent, but they all have these larger motorhomes, they believe that is their Godgiven right and I don't think that it is.

These misconceptions of past and present were also highlighted by other participants who noted that many New Zealanders are still holding on to the past when thinking about their domestic holidays and fail to be realistic with regard to the development of the country:

Group3_R4. My family had a holiday home in Wanaka which we sold in the mid-80s. We sold it in the mid-80s because in our mind, there were far too many people in Wanaka (laughing). [...] as a New Zealander, if you have to sit for quite some time in the car to wait that you can launch your boat or you are going to wait in a queue to get to a ski field and suddenly there are going too many bloody people, and too many bloody people means tourists. [...] I think that that is one of the big challenges that in people's memories, when they purchased property at some of these wonderful destinations and locations, they did that on the basis on that it was theirs, it was private and now they have to share it more and more with some other people who have also been seeing the same or similar benefits for them.

\section{The Future of Domestic Tourism in Aotearoa New Zealand}

While it is too early to see whether the COVID-19 crisis brings the hoped-for positive change towards more sustainability and resilience (Higgins-Desbiolles, 2020b; Pernecky, 2020) or it will be a missed opportunity of positive transformation (Hall et al., 2020), there is little doubt that domestic tourism will be the lifeline for many destinations to recover from COVID-19, including Aotearoa New Zealand (Seeler \& Lück, 2020). However, only if DMOs are more strategically considering domestic tourism in their overall strategies and policies can the 
desired positive transformation be realised beyond short-term recovery and towards destination and community resilience. This also requires a better understanding of the domestic demand and how the previous outward lens has influenced the travel behaviour and mindsets of New Zealanders. Findings from this research reveal three key themes related to domestic tourism pre-COVID-19: (1) Dispersal strategies have forced a spatial and temporal displacement; (2) Unrealistic domestic tourists holding on to the past; (3) Widespread blaming of 'others' and hiding own misbehaviour.

Prior to the pandemic, tourism marketing as well as infrastructure planning mostly targeted international demand and largely neglected the relevance of domestic tourists to ensure a sustainable development of the tourism industry across seasons and regions. Based on our findings and given the new circumstances created by COVID-19, we propose that governments and DMOs, particularly on a national level, need to consider the following implications related to a re-imagination of domestic tourism towards resilience building: (1) Domestic tourists need to be given a piece of their homeland back for re-exploration beyond the post-COVID-19 recovery stages. This will mean that they are not only seen as gap fillers in the shoulder season or less popular places, but they are more strategically be considered in overall destination strategies towards resilience building. (2) Educational campaigns, such as the Tiaki Promise (a pledge international tourists are asked to take - for more information see Tiaki New Zealand, 2020), need to be more inwardly-focussed to make sure that New Zealanders are 'walking-the-talk', become ambassadors and kaitiaki (guardians) of their homeland, and re-experience their own backyard responsibly. (3) Pricing of tourism products needs to be adjusted to a domestic market (see Seeler \& Lück, 2020). (4) Now is a good opportunity to actively encourage VFR (visiting friends and relatives) travel within the country.

While this paper geographically spotlights Aotearoa New Zealand, the findings will be of relevance to other destinations that targeted international tourists through promotional efforts and favoured them over domestic guests in overall growth strategies. Considering that the research was conducted in February 2020 when the actual magnitude of the COVID-19 pandemic was unclear and the critical importance of domestic tourism for industry survival was unimaginable, future research will be needed. Such research will be needed to explore how the re-vitalisation of the domestic demand supported crisis recovery strategies and how they can become a decisive driver in resilience building.

\section{References}

Ali, R. (2020, May 6). The winners \& loosers of a staycation world ahead. Retrieved from https://skift.com/2020/05/06/the-winners-losers-of-a-staycation-world-ahead/

Altunas, F., \& Gok, M. S. (2021). The effect of COVID-19 pandemic on domestic tourism: A DEMANTEL method analysis on quarnatibe decisions. International Journal of Hospitality Management, 92, Article 102719.

Ateljevic, I. (2020). Transforming the (tourism) world for good and (re)generating the potential 'new normal'. Tourism Geographies, 22(3), 467-475.

Braun, V., \& Clarke, V. (2006). Using thematic analysis in psychology. Qualitative Research in Psychology, 3(2), 77-101. 
Denscombe, M. (2017). The good research guide: For small-scale social research projects (6th ed.). Milton Keynes, U.k.: Open University Press.

Foon, E. (2020, May 6). Petition to ban all freedom camping when borders reopen. Retrieved from https://www.rnz.co.nz/news/national/416018/petition-to-ban-all-freedomcamping-when-borders-reopen

Geißler, M. (2020, August 1). Ostsee überfüllt: Mehrere Strände für Touristen dicht. Reisereporter. https://www.reisereporter.de/artikel/12291-ostsee-ueberfuellt-straendefuer-tagestouristen-dicht-strandampel-ist-rot

Gössling, S., Scott, D., \& Hall, C. M. (2020). Pandemics, tourism and global change: A rapid assessment of COVID-19. Journal of Sustainable Tourism. Advance online publication.

Hall, C. M., Prayag, G., \& Amore, A. (2018). Tourism and resilience: Individual, organisational and destination perspective. Bristol, U.K.: Channel View Publications.

Hall, C. M., Scott, D., \& Gössling, S. (2020). Pandemics, transformations and tourism: be careful what you wish for. Tourism Geographies, 22(3), 577-598.

Higgins-Desbiolles, F. (2020a, March 18). The end of global travel as we know it: An opportunity for sustainable tourism. The Conversation. Retrieved from https://theconversation.com/the-end-of-global-travel-as-we-know-it-an-opportunityfor-sustainable-tourism-133783

Higgins-Desbiolles, F. (2020b). Socialising tourism for social and ecological justice after COVID-19. Tourism Geographies, 22(3), 610-623.

Higham, J. (2020, July 2). The sun is setting on unsustainable long-haul, short-stay tourism regional travel bubbles are the future. The Conversation. Retrieved from https://theconversation.com/the-sun-is-setting-on-unsustainable-long-haul-short-staytourism-regional-travel-bubbles-are-the-future-140926

Hurley, S. (2019, June 13). Unruly tourists: British pair apologise to NZ for summer antics and frauds. New Zealand Herald. Retrieved from https://www.nzherald.co.nz/nz/news/article.cfm?c_id=1\&objectid=12240144

Insch, A. (2019). The challenges of over-tourism facing New Zealand: Risks and responses. Journal of Destination Marketing \& Management, 15, Article 100378.

Kravchenko, A. (2020, April 15). The future of tourism post-COVID-19.[Blog message]. Retrieved from https://www.unescap.org/blog/future-tourism-post-covid-19

Lück, M., \& Aquino, R. S. (in press). Domestic nature-based tourism and wellbeing - a road map for the New Normal? In J. Wilks, D. Pendergast, P. Leggat, D. \& Morgan (Eds.), Tourist health, safety and wellbeing post pandemic. Singapore: Springer Nature.

Niewiadomski, P. (2020). COVID-19: from temporary de-globalisation to a re-discovery of tourism? Tourism Geographies, 22(3), 651-656.

Pernecky, T. (2020). Critical tourism scholars: Brokers of hope. Tourism Geographies, 22(3), 657-666.

Prayag, G. (2020). Time for a reset? Covid-19 and tourism resilience. Tourism Review International, 24(2-3), 179-184. 
RND (2020, December 29). "Da ist die Hölle los": Schon wieder Verkehrschaos an deutschen Touristenzielen. Redaktionsnetzwerk Deutschland (RND). Retrieved from https://www.rnd.de/reise/verkehrschaos-und-corona-verstosse-in-harz-sauerlandschwarzwald-und-erzgebirge-SCI52KSZDVCP3CEYRNUPJRO2AY.html

Sabin, B. (2019, September 5). 100\% Pure crowds: Is over-tourism ruining New Zealand's gems? Stuff. Retrieved from https://www.stuff.co.nz/travel/news/115520007/100pure-crowds-is-overtourism-ruining-new-zealands-gems

Saldaña, J. (2016). The coding manual for qualitative researchers (3 ed.). Los Angeles, CA: SAGE

Seeler, S., \& Lück, M. (2020, May 4). The coronavirus survival challenge for NZ tourism: Affordability and sustainability. The Conversation. Retrieved from https://theconversation.com/the-coronavirus-survival-challenge-for-nz-tourismaffordability-and-sustainability-137256

Skirka, H. (2020, April 1). 13 brilliant tourism campaigns reminding us to 'dream now, visit later'. The National: $N$ Lifestyle. Retrieved from https://www.thenational.ae/lifestyle/travel/13-brilliant-tourism-campaigns-remindingus-to-dream-now-visit-later-1.1000211

Stats NZ. (2019a). Accommodation Survey - Guest nights by region (monthly). Stats NZ. Retrieved

from http://archive.stats.govt.nz/infoshare/ViewTable.aspx?pxID=eb30ce81-049c-4c03$810 \mathrm{c}-4 \mathrm{ccb} 11 \mathrm{~d} 0 \mathrm{dedb}$

Stats NZ. (2019b). Tourism satellite account: 2019. Stats NZ. Retrieved from https://www.stats.govt.nz/information-releases/tourism-satellite-account-2019

Tourism Industry Aotearoa. (2019a). Mood of the Nation New Zealanders' perceptions of international visitors - November 2019. Tourism Industry Aotearoa. Retrieved from https://www.tourismnewzealand.com/media/4054/mood-of-the-nation-nov-19.pdf

Tourism Industry Aotearoa. (2019b). Tourism 2025 and beyond: A sustainable growth framework. Tourism Industry Aotearoa. Retrieved from https://tia.org.nz/assets/d5156c4126/Tourism2025-and-Beyond-v2.pdf

Tourism New Zealand. (2019). Annual report 2018-2019. Tourism New Zealand. Retrieved from https://www.tourismnewzealand.com/media/4013/annual-report-2018-2019.pdf

Tourism New Zealand. (2020a). TNZ's domestic tourism focus supported by appointment of GM. Tourism New Zealand. Retrieved from https://www.tourismnewzealand.com/news/tnz-s-domestic-tourism-focus-supportedby-appointment-of-gm/

Tourism New Zealand. (2020b). Tourism New Zealand supports economic recovery from COVID-19. Tourism New Zealand. Retrieved from https://www.tourismnewzealand.com/news/tourism-new-zealand-supports-economicrecovery-from-covid-19/

Tourism New Zealand. (2021). About. Tourism New Zealand. Retrieved from https://www.tourismnewzealand.com/about/

TravelMole (2020, May 7). Global tourism could plummet by 80 per cent this year. TravelMole. 
https://www.travelmole.com/news_feature.php?news_id=2042587\&c=setreg\&region $=3$

United Nations. (2017). Global indicator framework for the sustainable development goals and targets of the 2030 agenda for sustainable development (A/RES/71/313). United Nations. Retrieved from https://unstats.un.org/sdgs/indicators/Global\%20Indicator\%20Framework_A.RES.71. 313\%20Annex.pdf

World Tourism Organization. (2020a, March 26). International tourist arrivals could fall by $20-30 \%$ in 2020. World Tourism Organization. Retrieved from https://www.unwto.org/news/international-tourism-arrivals-could-fall-in-2020

World Tourism Organization. (2020b, June 5). "Sustainability as the new normal" a vision for the future of tourism. World Tourism Organization. Retrieved from https://www.unwto.org/covid-19-oneplanet-responsible-recovery 